\title{
Pemahaman Konsep Matematika Melalui Pendekatan Reciprocal Teaching Pada Siswa Kelas X MAN Kuala Enok
}

\author{
Musa Thahir ${ }^{*}$ Zubaidah Amir MZ \\ * Universitas Islam Negeri Sultan Syarif Kasim Riau, Pekanbaru \\ musa.thahir@uin-suska.ac.id \\ ** Universitas Islam Negeri Sultan Syarif Kasim Riau, Pekanbaru \\ zubaidah.amir@uin-suska.ac.id
}

\section{INFO ARTIKEL}

\section{Riwayat Artikel:}

Diterima: 1 Maret 2019

Disetujui: 25 Juni 2019

\section{Kata kunci:}

Pemahaman Konsep Matematika Pendekatan Reciprocal Teaching Pembelajaran Konvensional Hasil Belajar

\section{Alamat Korespondensi:}

\begin{abstract}
ABSTRAK
Abstract: Understanding of mathematical concepts is one of the fundamental objectives in the learning process and one of the objectives of the material delivered by the teacher. However, one problem that often arises in learning mathematics is the low ability of students to solve mathematical problems that are packaged in the form of problems that emphasize the understanding of the concept of a particular subject. Seeing these problems, this article aims to determine differences in understanding of students' mathematical concepts through a reciprocal teaching approach. This article uses a quasi-experimental research model conducted at MAN Kuala Enok with a sample of 50 students. The data obtained were collected through test and documentation techniques which were analyzed by uncorrelated $t$ test. This article provides information that there are significant differences in the understanding of concepts between students who learn using the reciprocal teaching approach and students who obtain conventional learning.
\end{abstract}

\section{Zubaidah Amir MZ,}

Universitas Islam Negeri Sultan Syarif Kasim Riau, Provinsi Riau

Jalan Taman Karya, Panam, Pekanbaru 28293

E-mail: zubaidah.amir@uin-suska.ac.id

\begin{abstract}
Abstrak: Pemahaman konsep matematika merupakan salah satu tujuan yang mendasar dalam proses pembelajaran dan salah satu tujuan dari materi yang disampaikan oleh guru. Namun, salah satu masalah yang sering muncul dalam pembelajaran matematika adalah rendahnya kemampuan siswa dalam menyelesaikan masalah matematika yang dikemas dalam bentuk soal yang lebih menekankan pada pemahaman konsep suatu pokok bahasan tertentu. Melihat permasalahan tersebut, artikel ini bertujuan untuk mengetahui perbedaan pemahaman konsep matematika siswa melalui pendekatan reciprocal teaching. Artikel ini menggunakan model penelitian kuasi eksperimen yang dilakukan di MAN Kuala Enok dengan jumlah sampel 50 siswa. Data yang diperoleh terkumpul melalui teknik tes dan dokumentasi yang dianalisis dengan uji t yang tidak berkorelasi. Artikel ini memberikan informasikan bahwa terdapat perbedaan signifikan pemahaman konsep antara siswa yang belajar menggunakan pendekatan reciprocal teaching dengan siswa yang memperoleh pembelajaran konvensional.
\end{abstract}

\section{LATAR BELAKANG}

Salah satu bidang ilmu pengetahuan yang mempunyai peranan penting dalam perkembangan ilmu pengetahuan dan teknologi adalah matematika. Diberikannya pelajaran matematika untuk setiap jenjang pendidikan menunjukkan bahwa matematika merupakan salah satu dari sejumlah mata pelajaran yang penting dalam menghasilkan sumber daya manusia. Menurut Depdiknas Dirjen Pendasmen (2002) bahwa matematika adalah salah satu disiplin ilmu yang merupakan bagian dari proses pendidikan di sekolah dan mempunyai peranan penting dalam segala jenis dimensi kehidupan siswa dengan fungsinya untuk mengembangkan kemampuan menghitung, mengukur, dan sebagainya yang diperlukan dalam kehidupan sehari-hari. Mata pelajaran matematika itu sendiri memiliki tujuan 
agar peserta didik memiliki kemampuan: pemahaman konsep matematika, penalaran pada pola dan sifat, memecahkan masalah, mengkomunikasikan gagasan, dan memiliki sikap menghargai kegunaan matematika dalam kehidupan (Muslich, 2007). Berdasarkan tujuan mata pelajaran matematika tersebut, terlihat jelas bahwa matematika bertujuan agar siswa memiliki kemampuan pemahaman konsep dalam memecahkan permasalahan.

Pemahaman konsep matematika merupakan salah satu tujuan yang mendasar dalam proses pembelajaran dan salah satu tujuan dari materi yang disampaikan oleh guru. Namun, salah satu masalah yang sering muncul dalam pembelajaran matematika adalah rendahnya kemampuan siswa dalam menyelesaikan masalah matematika yang dikemas dalam bentuk soal yang lebih menekankan pada pemahaman konsep suatu pokok bahasan tertentu. Pemahaman konsep merupakan salah satu faktor psikologis yang diperlukan dalam kegiatan belajar. Karena dipandang sebagai suatu cara berfungsinya pikiran siswa dalam hubungannya dengan pemahaman bahan pelajaran, sehingga penguasaan terhadap bahan yang disajikan lebih mudah dan efektif (Sadirman, ). Kemampuan siswa yang rendah dalam aspek pemahaman konsep merupakan hal penting yang harus ditindaklanjuti (Thahir, 2012). Hal ini dikarenakan banyak siswa yang mencapai keberhasilan akademis tetapi hanya sedikit menunjukkan kemampuan pemahamannya dalam proses belajar mengajar. Padahal dalam konsep penilaian hasil belajar matematika siswa meliputi 5 aspek, yaitu: pemahaman konsep, pemecahan masalah, penalaran, komunikasi, dan koneksi (Fitriza, 2009).

Pemahaman terhadap konsep dan struktur suatu materi menjadikan materi itu dipahami secara lebih komprehensif lain dari itu peserta didik lebih mudah mengingat materi itu apabila yang dipelajari merupakan pola yang berstruktur. Dengan memahami konsep dan struktur akan mempermudah terjadinya transfer. Dengan kata lain pemahaman konsep yaitu memahami sesuatu kemampuan mengerti, mengubah informasi ke dalam bentuk yang bermakna.

Langkah-langkah dalam menanamkan suatu konsep matematika berdasarkan penggabungan beberapa teori belajar Bruner antara lain teori konstruksi, teori notasi, teori kekontrasan dan variasi serta teori konektivitas adalah sebagai berikut: 1) pengajar memberikan pengalaman belajar berupa contoh-contoh yang berhubungan dengan suatu konsep matematika dari berbagai bentuk yang sesuai dengan struktur kognitif peserta didik; 2) peserta didik diberikan dua atau tiga contoh lagi dengan bentuk pertanyaan; 3) peserta didik diminta memberikan contoh-contoh sendiri tentang suatu konsep sehingga dapat diketahui apakah peserta didik sudah mengetahui dan memahami konsep tersebut; 4) peserta didik mencoba mendefinisikan konsep tersebut dengan bahasanya sendiri; 5) peserta didik diberikan lagi contoh mengenai konsep dan bukan konsep; dan 6) peserta didik diberikan drill untuk memperkuat konsep tersebut (Intan, 2007). Menurut Badan Standar Nasional Pendidikan (2006) bahwa indikator yang menunjukkan pemahaman konsep antara lain: 1) menyatakan ulang sebuah konsep; 2) mengklasifikasikan objek-objek menurut sifat-sifat tertentu (sesuai dengan konsepnya); 3) memberi contoh dan non-contoh dari konsep; 4) menyajikan konsep dalam berbagai bentuk representasi matematis; 5) mengembangkan syarat perlu atau syarat cukup suatu konsep; dan 5) menggunakan, memanfaatkan, dan memilih prosedur atau operasi tertentu; serta 6) mengaplikasikan konsep atau algoritma pemecahan masalah.

Maka dari itu, upaya untuk meningkatkan pemahaman konsep siswa adalah salah satu prioritas utama dalam kegiatan pendidikan. Upaya tersebut menjadi tugas dan tanggung jawab semua pendidik. Oleh karena itu, perlu dikembangkan strategi mengajar inovatif yang dapat meningkatkan pemahaman konsep matematika dan melibatkan siswa untuk mandiri, kreatif dan lebih aktif. Salah satu strategi pembelajaran terbaru adalah pendekatan Reciprocal Teaching. Melalui pendekatan Reciprocal Teaching ini, siswa diharapkan belajar melalui "mengalami" bukan "menghafal". Pendekatan pengajaran terbalik (Reciprocal Teaching) merupakan suatu pendekatan terhadap pengajaran siswa akan strategi-strategi belajar (Trianto, 2007). Pengajaran terbalik (Reciprocal Teaching) adalah suatu prosedur pembelajaran yang dirancang untuk mengajari siswa empat strategi pemahaman mandiri, yaitu merangkum, membuat soal yang berkaitan dengan materi, menjelaskan dan memprediksi (Risnawati, 2008). Pada dasarnya pembelajaran ini menekankan pada siswa untuk bekerja dalam suatu kelompok yang dibentuk sedemikian hingga agar setiap anggotanya dapat berkomunikasi dengan nyaman dalam menyampaikan pendapat ataupun bertanya dalam rangka bertukar pengalaman keberhasilan belajar satu dengan lainnya. Salah satu dasar dari pembelajaran ini adalah teori Vygotsky yaitu dialog dalam suatu interaksi sosial sebagai dasar pokok dalam proses pembentukan pengetahuan. Menurut Vygotsky bahwa proses pembelajaran akan terjadi jika anak bekerja atau menangani tugastugas yang belum dipelajari, namun tugas-tugas tersebut masih berada dalam jangkauan mereka disebut dengan zone of proximal development, yaitu daerah tingkat perkembangan sedikit ke atas dari perkembangan seseorang saat ini (Trianto, 2007).

Menurut Palinscar dan Brown, yang dikutip Nur bahwa pendekatan pengajaran terbalik terutama dirancang untuk membantu siswa yang rendah hasil belajarnya dalam membaca dan pemahaman yang melibatkan kelompok kecil siswa. Sehingga dengan penggunaan pendekatan ini mampu meningkatkan hasil belajar siswa yang rendah. Manfaat Reciprocal Teaching adalah dapat meningkatkan antusias siswa dalam pembelajaran karena siswa dituntut untuk aktif berdiskusi dan menjelaskan hasil pekerjaannya dengan baik sehingga pemahaman konsep suatu pokok bahasan matematika dapat dicapai. Dari uraian tersebut, dapat dikemukakan bahwa pendekatan pengajaran terbalik 
(Reciprocal Teaching) merupakan strategi dalam pembelajaran yang menekankan pada pemahaman mandiri siswa, sehingga dapat mempengaruhi pemahaman konsep matematika siswa. Berdasarkan uraian tersebut, maka artikel ini memiliki tujuan untuk melihat ada atau tidaknya perbedaan pemahaman konsep matematika antara siswa yang belajar menggunakan pendekatan reciprocal teaching dan siswa yang menggunakan pembelajaran konvensional di MAN Kuala Enok.

\section{METODE}

Artikel ini menggunakan model penelitian kuasi eksperimen yang dilaksanakan di MAN Kuala Enok dengan subjek dalam penelitian ini adalah siswa kelas X Madrasah Aliyah Negeri Kuala Enok sedangkan objek dalam penelitian ini adalah pemahaman konsep siswa. Populasi dalam penelitian ini adalah seluruh siswa kelas X semester 2 MAN Kuala Enok Tahun Pelajaran 2011/2012 sebanyak 50 peserta didik yang terbagi dalam 2 kelas, yaitu kelas X-1 sebanyak 25 siswa dan X-2 sebanyak 25 siswa. Sampel yang akan diambil dalam penelitian ini adalah seluruh siswa kelas X dengan menggunakan sampel penuh. Di mana kelas X-1 sebagai kelas eksperimen yang akan digunakan pendekatan Reciprocal Teaching dan kelas X-2 sebagai kelas kontrol dengan model pembelajaran konvensional. Teknik yang digunakan dalam pengumpulan data dalam artikel ini antara lain: observasi, dokumentasi dan tes serta angket. Sebelum tes dilakukan, tes tersebut harus terlebih dahulu memenuhi persyaratan dengan menggunakan bantuan program ANATES versi 4.0.5. Hasil uji coba tes menunjukkan bahwa: 1) semua butir soal dalam tes pemahaman konsep adalah valid; 2) hasil ujicoba reliabilitas butir soal secara keseluruhan diperoleh koefisien reliabilitas tes sebesar 0,59 yang berarti bahwa tes pemahaman konsep matematika mempunyai reliabilitas yang sedang; 3) sebanyak tujuh soal tes pemahaman konsep merupakan soal dengan kategori soal sedang; dan 4) dari tujuh soal tes pemahaman konsep tersebut hanya satu yang mempunyai daya pembeda cukup, dua mempunyai daya pembeda yang baik dan empat mempunyai daya pembeda yang sangat baik. Berdasarkan hasil analisis validitas, reliabilitas, daya pembeda, dan tingkat kesukaran maka tes pemahaman konsep yang telah diujicobakan dapat digunakan sebagai instrumen pada penelitian ini. Data yang telah terkumpul kemudian dianalisis menggunakan uji $\mathrm{t}$ untuk kelompok sampel yang tidak berkorelasi. Sebelum melakukan analisis data dengan test " $\mathrm{t}$ " ada dua syarat yang harus dilakukan, yaitu uji normalitas dan uji homogenitas.

\section{HASIL}

Harap periksa semua gambar dalam jurnal Anda, baik di layar, maupun hasil versi cetak. Ketika memeriksa gambar versi cetak, pastikan bahwa:

\section{Uji Homogenitas}

Uji Homogenitas yang peneliti lakukan adalah uji varians terbesar dibanding varians terkecil dengan menggunakan tabel F. Pengujian Homogenitas yang peneliti lakukan adalah dari hasil postes. $F_{\text {hitung }}$ untuk kelas eksperimen dan kelas kontrol yang diperoleh adalah lebih kecil dari $F_{\text {tabel. }}$ Selanjutnya,dapat disimpulkan bahwa varians tersebut adalah homogen. Hasil rangkuman disajikan pada tabel 1 berikut.

Tabel 1. Uji Homogenitas

\begin{tabular}{cccc}
\hline $\mathrm{F}_{\text {hitung }}$ & $\mathrm{Df}$ & $\mathrm{F}_{\text {tabel }} 5 \%$ dan $1 \%$ & Kriteria \\
\hline 1,142 & 48 & 1,98 & Homogen \\
\hline
\end{tabular}

\section{Uji Normalitas}

Kemampuan akhir siswa dilihat berdasarkan skor postes dari kedua kelas penelitian yaitu kelas eksperimen yang mengikuti pendekatan Reciprocal Teaching dan kelompok kontrol yang mengikuti pembelajaran konvensional. Selanjutnya skor postes diolah dengan menggunakan rumus chi kuadrat untuk menguji normalitas. Berdasarkan hasil penelitian, dapat diamati bahwa nilai $\chi_{\text {hitung }}^{2}$ kelas eksperimen sebesar 8,41 sedangkan untuk nilai $X_{\text {hitung }}^{2}$ kelas kontrol sebesar 15,7. Harga $\chi^{2}{ }_{\text {tabel }}$ dalam taraf signifikansi 5\% unutk kelas eksperimen sebesar 15,51 dan kelas kontrol sebesar 19,68. Dengan demikian $X^{2}{ }_{\text {hitung }}<X_{\text {tabel }}{ }$ maka dapat dikatakan bahwa data berasal dari populasi yang berdistribusi normal. Hasil pengujian normalitas bagi skor postes untuk kelas kontrol dan kelas eksperimen selengkapnya dapat dilihat pada Tabel 2 berikut.

Tabel 2. Uji Normalitas

\begin{tabular}{cccc}
\hline Kelas & $\chi_{\text {hitung }}^{2}$ & $\chi_{\text {tabel }}^{2}$ & Kriteria \\
\hline Eksperimen & 8,41 & 15,51 & Normal \\
Kontrol & 15,7 & 19,68 & Normal \\
\hline
\end{tabular}




\section{Uji Hipotesis}

Karena telah memenuhi kedua syarat tersebut, kemudian dilanjutkan analisis data dengan tes " $\mathrm{t}$ " untuk sampel besar $(\mathrm{N} \geq 30)$ yang tidak berkorelasi. Nilai $t_{\text {hitung }}=2,6957$ berarti bahwa thitung lebih besar $t_{\text {tabel }}$ pada taraf signifikan $5 \%$ maupun taraf signifikan $1 \%$ dengan $\mathrm{df}=\mathrm{Nx}+\mathrm{Ny}-2=25+25-2=48$. Dalam tabel tidak terdapat $\mathrm{df}=48$, maka dari itu digunakan df yang mendekati 48 yaitu $\mathrm{df}=50$. Dengan df diperoleh dari ttabel pada taraf sidnifikan $5 \%$ dan $1 \%$ sebesar 2,01 dan 2,68. Ini berarti $t_{\text {hitung }}>t_{\text {tabel }}$, maka diputuskan bahwa HO ditolak dan Ha diterima. Dengan demikian, dapat disimpulkan bahwa terdapat perbedaan pemahaman konsep antara siswa yang belajar menggunakan pendekatan Reciprocal Teaching dengan siswa yang memperoleh pembelajaran konvensional. Hasil perhitungan selengkapnya dapat dilihat pada Tabel 3 berikut.

Tabel 3. Uji Tes "t"

\begin{tabular}{cccccc}
\hline Kelas & Perbedaan & $t_{\text {hitung }}$ & df & $t_{\text {tabel }}$ & Ho \\
\hline $\begin{array}{c}\text { Eksperimen } \\
\text { Kontrol }\end{array}$ & $80,6000>70,600$ & 2,6957 & 48 & 2,01 & Tolak \\
\hline
\end{tabular}

\section{PEMBAHASAN}

Berdasarkan $t_{0}$ tentang pemahaman konsep siswa pada pokok bahasan perbandingan dan fungsi trigonometri bahwa mean menunjukkan pemahaman konsep kelas yang menggunakan pendekatan Recirocal Teaching lebih tinggi daripada mean pemahaman konsep kelas konvensional. Hal ini menunjukkan bahwa penerapan pendekatan Recirocal Teaching dalam pembelajaran matematika memiliki perbedaan yang signifikan di mana hasil belajar kelas eksperimen lebih tinggi dari kelas kontrol. Sebagaimana yang dikatakan Sugiyono (2010) bahwa jika kelompok treatment lebih baik dari pada kelompok kontrol, maka perlakuan yang diberikan pada kelompok treatment berpengaruh positif. Berdasarkan hasil observasi dapat dilihat bahwa pembelajaran dengan menggunakan pendekatan Reciprocal Teaching dapat membuat siswa selalu aktif dengan melakukan berbagai kegiatan untuk menguasai bahan pelajaran sepenuhnya. Karena dalam pembelajaran ini siswa dapat menjelaskan materi kepada siswa lain, mendengarkan penjelasan dari teman secara aktif, bertanya dengan siswa-guru, berdiskusi dengan siswa lain, menanggapi pertanyaan dan argumentasi. Semakin aktif siswa dalam belajar maka pemahaman siswa makin bertambah. Hal ini tampak dari sikap siswa ketika mengikuti pelajaran dengan semangat dan penuh antusias. Dengan demikian hasil analis ini mendukung rumusan masalah yang diajukan yaitu terdapat perbedaan pemahaman konsep antara siswa yang belajar menggunakan pendekatan Reciprocal Teaching dengan siswa yang memperoleh pembelajaran konvensional.

Penelitian ini mendukung penelitian terdahulu sebagaimana yang telah dilakukan oleh Ratnasari yang mengemukakan bahwa pendekatan Reciprocal Teaching dapat meningkatkan hasil belajar siswa sebesar $80 \%$, yang merupakan bagian dari pemahaman konsep. Berdasarkan penelitian ini, peneliti menganalogikan aktivitas-aktivitas penemuan dalam pendekatan Reciprocal Teaching sebagai permainan yang menarik bagi siswa. Hal ini dimungkinkan karena pembelajaran telah berubah dari paradigma pembelajaran yang berpusat pada guru kepada pembelajaran yang menekankan pada keaktifan siswa untuk mengkonstruksi pengetahuannya sendiri melalui tantangan masalah, aktivitas penemuan. Kondisi ini diperkuat oleh pendapat Suryadi yang dikutip oleh Mimi Hariyani yang menyatakan bahwa dengan terjadinya interaksi antar siswa akan diperoleh banyak keuntungan, antara lain sharing pengetahuan dan pendapat, refleksi atas hasil pemikiran masing-masing, dan akhirnya akan bermuara pada peningkatan pemahaman untuk masing-masing anggota kelompok. Selanjutnya menurut Turmudi dalam Hariyani (2010) mengemukakan bahwa untuk memberikan dukungan wacana kelas secara lebih efektif, guru harus membangun masyarakat di mana siswa merasa bebas mengemukakan gagasannya. Oleh karena itu, bantuan guru sangat diharapkan dan diperlukan proses belajar mengajar dapat berjalan lancar sehingga gagasan yang dikemukakan siswa dapat dipahami oleh temannya yang lain.

\section{SIMPULAN DAN SARAN}

\section{Simpulan}

Berdasarkan hasil penelitian, dapat diambil kesimpulan bahwa terdapat perbedaan signifikan pemahaman konsep antara siswa yang belajar menggunakan pendekatan Reciprocal Teaching dengan siswa yang memperoleh pembelajaran konvensional. Hal ini diperoleh dari nilai thitung $=2,6957$ berarti bahwa thitung lebih besar tabel pada taraf signifikan 5\% maupun taraf signifikan $1 \%$ dengan $\mathrm{df}=\mathrm{N}_{\mathrm{x}}+\mathrm{N}_{\mathrm{y}}-2=25+25-2=48$. Dalam tabel tidak terdapat $\mathrm{df}=48$, maka dari itu digunakan $\mathrm{df}$ yang mendekati 48 yaitu $\mathrm{df}=50$. Dengan $\mathrm{df}$ diperoleh dari tabel pada taraf sidnifikan $5 \%$ dan $1 \%$ sebesar 2,01 dan 2,68. Ini berarti $t_{\text {hitung }}>t_{\text {tabel }}$, maka diputuskan bahwa $\mathrm{H}_{0}$ ditolak dan $\mathrm{H}_{\mathrm{a}}$ diterima. 


\section{Saran}

Berdasarkan kesimpulan dari penelitian, dapat dikemukakan saran-saran sebagai berikut: 1) untuk menerapkan pembelajaran dengan pendekatan Reciprocal Teaching, sebaiknya guru membuat sebuah skenario dan perencanaan yang matang, sehingga pembelajaran dapat terjadi secara sistematis sesuai dengan rencana, dan pemanfaatan waktu yang efektif dan tidak banyak waktu yang terbuang oleh hal-hal yang tidak bermanfaat; 2) bahasan matematika yang dikembangkan dalam penelitian ini hanya terdiri dari dua kompetensi dasar. Masih terbuka peluang bagi peneliti lain untuk bereksperimen pada standar kompetensi yang lainnya; dan 3) penelitian ini dilakukan terhadap siswa MAN Kuala Enok Kecamatan Tanah Merah yang jumlah siswanya relatif sedikit. Oleh karena itu, perlu penelitian lebih lanjut pada sekolah-sekolah lain yang jumlah siswanya lebih banyak dengan melakukan pembiasaan terlebih dahulu terhadap para siswa agar hasilnya lebih maksimal.

\section{DAFTAR RUJUKAN}

Badan Standar Nasional Pendidikan. 2006. Model Penilaian Kelas, Jakarta: Depdiknas.

Depdiknas Dirjen Pendasmen. 2002. Kurikulum Berbasis Kompetensi. Jakarta: Direktorat Pendidikan.

Fitriza, Rozi. 2009. Penilaian Berbasis Kelas (Classroom Assesment) dalam Pembelajaran Matematika. Dipresentasikan dalam seminar Nasional Fakultas Tarbiyah dan Keguruan UIN Suska Riau Pekanbaru.

Hariani, Mimi. 2010. Pembelajaran Matematika Dengan Metode Penemuan Terbimbing Untuk Meningkatkan Pemahaman Konsep Dan Kemampuan Penalaran Matematik Siswa Sekolah Dasar. Bandung: Program Studi Magister Pendidikan Dasar Sekolah Pasca Sarjana Universitas Pendidikan Indonesia. (tidak diterbitkan)

Intan, Dewi Mahabbah. 2007. Model Pembelajaran Posing Tipe Post Solution Posing untuk Mengajarkan Pemahaman Konsep Matematika Pokok Bahasan Bangun Segi Empat Pada Peserta Didik Kelas VII SMP Negeri I Balapulang Tegal. Semarang: Fakultas Matematika dan Ilmu Pengetahuan Alam. (tidak diterbitkan)

Muslich, Masmur. 2007. Kurikulum Tingkat Satuan Pendidikan. Jakarta: PT. Bumi Aksara.

Risnawati. 2008. Strategi Pembelajaran Matematika. Pekanbaru: Suska Press.

Sardiman, A.M. 2001. Interaksi dan motivasi Belajar Mengajar. Jakarta: PT Raja Grafindo Persada.

Sugioyono. 2007. Metode Penelitian Pendekatan Kuantitatif, Kualitatif, dan REED. Bandung: Alfabeta

Thahir, Musa. 2012. Penerapan Pembelajaran Matematika dengan Menggunakan Pendekatan Reciprocal Teaching terhadap Pemahaman Konsep Siswa Kelas X MAN Kuala Enok Kecamatan Tanah Merah Kabupaten Indragiri Hilir. Skripsi. Universitas Islam Negeri Sultan Syarif Kasim Riau. (tidak diterbitkan)

Trianto. 2007. Model-Model Pembelajaran Inovatif Berorientasi Konstruktivistik. Jakarta: Prestasi Pustaka Publisher. 